\title{
MANAJEMEN PERUBAHAN ORGANISASI SEBAGAI UPAYA PENINGKATAN KINERJA PERUSAHAAN DI INDUSTRI BATIK LAWEYAN SURAKARTA
}

\author{
Lukman Hakim ${ }^{1}$ dan Eko Sugiyanto ${ }^{2}$ \\ ${ }^{1}$ Fakultas Ekonomi dan Bisnis Universitas Muhammadiyah Surakarta \\ ${ }^{2}$ Fakultas Ekonomi dan Bisnis Universitas Muhammadiyah Surakarta \\ Email: Lukman.Hakim@ums.ac.id,Ekosugiyanto_01@yahoo.com
}

\begin{abstract}
Abstrak-Tujuan penelitian ini adalah: (1) Mengidentifikasi penyebab perubahan organisasi yang terjadi di industri Batik Laweyan Surakarta. (2) Mengidentifikasi dampak perubahan organisasi di industri Batik LaweyanSurakarta. (3) Menganalisis proses perubahan organisasi yang terjadi di industri Batik LaweyanSurakarta. (4) Menganalisis faktor pendukung perubahan organisasi di industri Batik LaweyanSurakarta. Hasil penelitian menyimpulkan bahwa penyebab perubahan organisasi: (1) karena pemenuhan kebutuhan dan selera konsumen, (2) adanya persaingan dari competitor pengusaha batik, (3) karena kondisi perekonomian di Indonesia yang fluktuatif. (4) Adanya masalah pendidikan dan kemampuan keuangan perusahaan batik, (5) faktor lingkungan sekitar. Proses pelaksanaan perubahan yang terjadi di Industri Batik Laweyan secara umum adalah berkarakter sama yaitu karakter tenang dan teratur secara evolusi atau tahapan-tahapan (midle of change). Faktor pendukung perubahan, antara lain: (1) pihak pemerintah, (2) lembaga pelindung (Forum Forum Pengembangan Kampoeng Batik Laweyan/ FPKBL), (3) Kebijakan perusahaan, (4) bahan-bahan yang digunakan untuk melakukan inovasi dalam proses pewarnaan mudah didapatkan. Sumber penolakan terhadap perubahan oganisasi, antara lain:(1) kekhawatiran akan munculnya pesaing-pesaing baru, (2) Beragamnya ide atau gagasan pengusaha batik.
\end{abstract}

Kata Kunci: Peyebab perubahan organisasi, Dampak perubahan strategi, proses perubahan dan penghambat perubahan strategi

\begin{abstract}
The purpose of this study are: (1) Identify the causes of organizational changes that occur in Batik Laweyan Surakarta industry. (2) Identify the impact of organizational change in Batik Laweyan Surakarta industry. (3) Analyzing organizational change process that happened in Batik Laweyan Surakarta industry. (4) Analyzing the constraining factors and supporting organizational change in Batik Laweyan Surakarta industry. The result of the research concludes that the cause of organizational change: (1) because the fulfilment of consumer needs and tastes, (2) competition from batik entrepreneurs, (3) due to fluctuating economic condition in Indonesia. (4) The existence of education problem and financial ability of batik company, (5) environmental factor around. The process of execution of changes that occurred in Batik Laweyan industry in general is the same character that is the character of calm and orderly by evolution or stages (midle of change). Factors supporting the change include: (1) the government, (2) the protective institutions(Kampoeng Batik Laweyan Development Forum), (3) company policy, (4) the materials used to innovate in the process of easy staining obtained. Source of rejection to change of organization, among others: (1) concern about the emergence of new competitor, (2) Variety of idea batik entrepreneur.
\end{abstract}

Keywords: Causes of organizational change, Impact of strategy change, and organizationalchange process

\section{PENDAHULUAN}

Organisasi modern dewasa ini dalam menghadapi berbagi permasalahan. Pemasalahan baik di bidang keuangan, SDM, operasional dan lain-lain.Sebagai penyelesaiannya perusahaan tidak bisa tidak atau harus mengadakan perubahan. Sebuah organisasi yang mengabaikan konsep perubahan akan mengalami dampak buruk yang timbul dikemudian hari.

Para manajer efektif perlu memandang kegiatanmerekadalamhalmengelolaperubahan sebagai suatu tanggung jawab yang bersifat integral, dan bukan sekadar sebagai kegiatan yang sambil lalu. Perubahan juga melibatkan pemikiran individu-individu, kelompokkelompok di dalam suatu organisasi itu sendiri, 
yang pada akhirnya berarti perubahan pada perilaku keorganisasian. Mengelola perubahan dan studi tentang perubahan, memerlukan pemahaman sejumlah disiplin-disiplin ilmu sosial yang bersifat interdisipliner.

Keefektifan sebuah perubahan juga harus dibarengi dengan penerapan strategi perusahaan dan juga pengembangan strategi perubahan organisasi. Sebagaimana hasil penelitian Rindaningsih (2012) tentang pengembangan model manajemen Stratejik di sebuah lembaga pendidikan di Sidoarjo Jawa Timur menghasilkan temuan bahwa pengembangan stratejik sangat efektif dalam mengatasi berbagai problematik di sekolahan dan perlunya peran maksimal pimpinan/ kepala sekolah dalam proses perubahan. Hasil penelitian Abdul Mukhlis (2010) tentang implementasi manajemen strategis dalam upaya peningkatan mutu pendidikan pada pondok pesantren di Jombang Jawa Timur menghasilkan temuan bahwa implementasi manajemen strategis dalam upaya peningkatan mutu pendidikan sudah terlaksana dengan baik di lembaga pesantren tersebut. Usaha peningkatan mutu pendidikan mulai meningkat dan terarah karena penerapan manajemen strategis yang diterapkan oleh Pesantren dapat dilaksanakan dan tercapai dengan baik.

Penelitian proses perubahan antara lain penelitian Anjali Bansal (2015) yang melaporkan sebuah studi mekanisme pasca-integrasi dilakukan oleh lima merger multinasional dan akuisisi (M \& A) transaksi terjadi dalam konteks India. Studi ini telah terjalin sekitar konsep integrasi manusia dan integrasi tugas sebagai tujuan yang terpisah dari memperoleh organisasi yang akan dicapai.Penelitian ini didasarkan pada desain penelitian deskriptif. Data kualitatif dikumpulkan, di mana manajer dari organisasi memperoleh dan karyawan dari perusahaan yang diakuisisi telah mengambil bagian dalam proses pengumpulan data melalui wawancara. Hasil penelitian menunjukkan bahwa organisasi di mana mekanisme integrasi manusia diberi kepercayaan karena juga memendam karyawan sangat berkomitmen dari rekan-rekan organisasi mereka, sedangkan transaksi di mana tujuan integrasi tugas diberikan preferensi sementara mengabaikan integrasi manusia, karyawan mengembangkan emosi negatif dari kemarahan dan rasa tidak aman karena mereka yang baru bergabung perusahaan.

Penelitian Rodriguez et.all (2016) yang menganalisis perubahan organisasi tertentu yang terjadi setelah privatisasi, dimana lebih khusus, peneliti menganalisis dari perspektif teori keagenan bagaimana perubahan pada tingkat tata kelola perusahaan (tipe kepemilikan / struktur dan dewan direksi) mempengaruhi strategi perusahaan, dan apa implikasi masalah ini harus untuk desain mekanisme kompensasi. Hasil penelitian : (1) variabel yang secara tradisional berhubungan dengan kebebasan taktikperubahan yang lebih besar dalam pemantauan tidak terikat setelah privatisasi. (2) kepentingan kepemilikan baru perusahaan 'berdampak pada strategi perusahaan setelah privatisasi. Akhirnya, desain sistem kompensasi jelas sejalan dengan strategi perusahaan setelah privatisasi.

Salah satu masalah yang di hadapi perubahan di organisasi adalah mencoba mencocokaan model-model perubahan dengan pengalaman praktis. Model perubahan tersebut nantinya berkaitan dengan proses perubahan.Model formal perubahan umumnya mengesankan perubahan sebagai rentetan aktivitas atau tahap-tahap yang teratur dan rapi. Justru berkebalikan dari itu, pengalaman yang sesungguhnya biasanya lebih messy (berantakan), dimana berbagai aktivitas kerap berjalan parallel. Tahap-tahap tertentu acap berulang-ulang saat rancangan organisasi baru atau kebijakan pemasaran baru dicoba karena ternyata semua itu tidak jalan.

Penelitian Anna Pluta \&Aleksandra Rudawska (2016) yang meneliti model pendekatan holistik untuk sumber daya manusia dalam situasi percepatan organisasi. Peneliti merumuskan bahwa pendekatan holistik untuk HR membantu dalam menjaga sumber daya yang berkelanjutan individu karyawan dalam situasi perubahan organisasi terus menerus dan tekanan waktu yang lebih lanjut dapat mencegah dari kelelahan sumber dayaindividu. Hasilpenelitiannya dalam situasi fungsi percepatan HRM organisasi memainkan peran penting dalam mempertahankan sumber daya individu karyawan untuk meminimalkan ancaman stres kerja dan burnout lebih lanjut. praktik HR harus menerapkan multidimensi sumber daya individu dan ancaman itu secara holistik bertujuan mempertahankan keempat 
potensi - spiritual, intelektual, emosional dan fisik.

Perubahan di sebuah organisasi memberi banyak peran dan pengaruh positif terhadap kinerja karyawan dan organisasi. Penelitian Gail F. Latta(2015) yang bertujuan memperjelas peran budaya organisasi dalam mengatur dinamika perlawanan dan fasilitasi perubahan dengan memberi penjelasan mekanisme operasional yang mendasari model perubahan organisasi dalam konteks budaya organisasi. Temuanpenelitian ini menjelaskan bahwa dua sumber resistensi dan fasilitasi yang digambarkan, baik yang berasal dari tingkat keselarasan budaya konten (inisiatif strategis) dan proses (strategi implementasi) unsur perubahan strategis. Interaksi dinamis sumber-sumber independen perlawanan dan fasilitasi dieksplorasi dalam konteks model budaya organisasi dimana konsekuensi dari keselarasan budaya dianggap sehubungan dengan mengubah pelaksanaan dan terkait dengan teori bukti empiris.

Penelitian Safal Batra (2016) dengan tujuan menganalisis apakah perubahan selalu alternatif terbaik? Sementara perusahaan besar dan mapan diyakini manfaat dari fleksibilitas strategis dan perubahan, tujuan dari penelitian ini adalah untuk membuktikan secara empiris bahwa perusahaan di negara-negara berkembang perlu bertahan dengan strategi mereka selama tahun-tahun dalam rangka untuk memperoleh keunggulan kompetitif yang berkelanjutan. Temuan mengungkapkan bahwa bertahan dengan strategi yang ada adalah cara yang paling optimal untuk bertahan hidup dan berkembang di tahun-tahun awal usaha yang beroperasi di lingkungan bisnis turbulen dari negara berkembang. Perubahan radikal dalam postur strategis dapatberakibat fatal bagi perusahaan-perusahaan baru.

Seiring adanya peningkatan minat dan permintaan pasar batik dari berbagai kalangan tersebut, meningkat pula geliat produksi batik dari industri batik di dalam negeri. Distribusi batik juga mengalami peningkatan terutama ekspor ke luar negeri. Terbukti peningkatan pasar batik terutama diluar negeri pun meningkat cukup tinggi setelah pengakuan dari UNESCO sebagai warisan budaya asli Indonesia pada 2 Oktober 2009. Berdasarkan data Kemenperin, ekspor batik dalam lima tahun terakhir meningkat pesat. Ekspor batik yang pada tahun 2011 senilai 2.287.668,04 Dolar AS dengan volume 93.559,29 kg meningkat menjadi 48,97 juta dollar AS pada tahun 2014. Ekspor batik tersebut terutama ke Amerika Serikat, Jerman dan Korea Selatan (Kompas, 6 Oktober 2015).

Salah satu industri batik terkenal di kota Surakarta adalah kampung batik Laweyan. Masyarakat Laweyan dari zaman kerjaan Pajang sampai sekarang merupakan daerah penghasil batik. Meskipun dalam perkembangannya mengalami pasang surut dalam usahanya tetapi masyarakatnya masih tetap eksis dalam bidang perbatikan. Sejak dicanangkannya Laweyan sebagai kampong wisata batik dengan SK Walikota Surakarta Nomor 534.05/136-B/1/2004, maka perkembangan industri batik dikampung Laweyan mengalami kemajuan yang pesat. Hal ini dapat dilihat dari banyaknya wisatawan yang berkunjung untuk berbelanja batik sekaligus belajar membatik serta menikmati bangunan-bangunan peninggalan yang bersejarah (Setiawati dan Nursiam, 2013). Hal ini secara tidak langsung membawa pengaruh positif pada industry batik Laweyan yang ditandai dengan meningkatnya omset penjualan. Namun dibalik meningkatnya penjualan tersebut terdapat sejumlah permasalahan di manajemen batik yang masih bersifat tradisional. Masalah tersebut diantaranya masalah kurang kompetitifnya produk batik, masalah SDM yaitu keluar masuknya tenaga kerja/ karyawan, kurangnya tenaga pembatik pengganti dari kalangan tenaga muda di Laweyan sekitarnya. Pada umumnya tenaga pembatik berasal dari desa sekitar pinggiran kota Surakarta sekitarnya (Setiawati dan Nursiam, 2013).

Mengingat kondisi demikian perlu adanya penelitian pengelolaan perubahan strategi perusahaan batik, sehingga dapat diidentifikasi penyebab perubahan strategi, akibat dan model pengembangan strategi perubahan sebagai upaya peningkatan kinerja industri Batik Laweyan Surakarta. Tujuan penelitian ini : (1) Mengidentifikasi penyebab perubahan organisasi yang terjadi di industri Batik Laweyan Surakarta. (2) Mengidentifikasi akibat atau dampak perubahan organisasi baik secara individu maupun organisasional diindustri Batik LaweyanSurakarta. (3) Mengidentifikasi 
karakteristik perubahan organisasi dari segi proses yang terjadi di industri Batik LaweyanSurakarta. (4) Menganalisis faktor pendukung perubahan organisasidi industri Batik Laweyan Surakarta.

\section{METODE PENELITIAN}

\section{Jenis Penelitian}

Jenis penelitian ini menggunakan metode deskriptip dengan pendekatan studi kasus (Case Studies). Studi kasus merupakan penelitian yang mendalam tentang individu, satu kelompok, satu organisasi, satu program kegiatan, dan sebagainya dalam waktu tertentu. Tujuannya untuk memperoleh diskripsi yang utuh dan mendalam dari sebuah entitas. Studi kasus menghasilkan data untuk selanjutnya dianalisis untuk menghasilkan teori yang bisa diterapkan pada obyek baik masyarakat atau perusahaan. Sebagaimana prosedur perolehan data penelitian kualitatif, data studi kasus diperoleh dari wawancara, observasi, dan dokumentasi atau arsip. Studi kasus dalam penelitian ini dipakai untuk meneliti perubahan organisasi di industri batik Laweyan Surakarta, di mana para pengusahanya bisa mencapai prestasi luar biasa yaitu mengangkat pemasaran produknya yang bersifat lokal menjadi internasional.

Untuk mendapatkan data yang benarbenar valid, maka pemeriksaan keabsahan data menggunakan tehnik triangulasi yaitu pengecekan atau sebagai pembanding terhadap data tersebut. Menurut Patton dalam H.B. Sutopo (2002) terdapat empat macam tehnik triangulasi, yaitu triangulasi data, triangulasi metode, triangulasi peneliti dan triangulasi teori.Dalam penelitian ini, triangulasi yang dipakai adalah triangulasi metode. Dengan alasan dalam triangulasi metode lebih ditekankan pada penggunaan metode pengumpulan data yang berbeda seperti observasi dan wawancara mendalam dan bahkan lebih jelas untuk diusahakan mengarah pada sumber data yang sama untuk menguji kemantapan informasinya.

\section{Pengumpulan Data dan Analisis Data}

Data yang dibutuhkan dalam penelitian ini adalah :
1. Data primer

Data primer yang diperlukan dalam penelitian ini didapatkan melalui kuisioner, observasi, wawancara tertutup, serta diskusi kelompok terarah (Focused group discussion/FGD). Observasi dilakukan dengan jalan mengadakan pengamatan secara langsung terhadap obyek penelitian yaitu menghasilkan data kualitatif untuk mengidentifikasi peluang, ancaman, kekuatan serta ancaman industri.

\section{Data sekunder}

Data sekunder meliputi antara lain kondisi lingkungan sosial, organisasi yang didapatkan dari dokumentasi Batik Putra Laweyan, Batik Mahkota, Batik Merak Manis, Batik Puspa Kencana dan Batik Gres Tenan.Data sekunder juga berasal dari studi pustaka dilakukan untuk mendapatkan teori-teori ataupun data empiris yang berasal dari jurnal hasil penelitian, perpustakaan, internet maupun laporan dinas yang berkait.

\section{HASIL DAN PEMBAHASAN}

\section{Penyebab Perubahan}

Dari hasil analisis data dilapangan ditemukan beberapa identifikasi penyebab perubahan organisasi yang terjadi di industri batikKampung Laweyan, antara lain: Penyebab pertama oleh karena pemenuhankebutuhan dan selera konsumen. Sebab atau alasan untuk menghasilkan perubahan didasari oleh kebutuhan individual terutama yang berkaitan dengan keinginan dan selera konsumen, seperti penuturan dari pemilik Batik Puspa Kencana berikut:

"Kami selalu berusaha memenuhi produk yang diinginkan konsumen, sehingga produkproduk batik yang diproduksi menyesuaikan pelanggan. Apalagi pelanggan kami mayoritas berasal dari Malaysia yang sudah mengenal batik khas Solo" (wawancara dengan bapak Ahmad sulaiman, 22 Maret 2018).

Hal ini terbukti dari pengamatan tim peneliti yang melihat mayoritas produk yang dihasilkan oleh Batik Puspa Kencana berbeda dengan model-model pakaian yang ada pada umumnya.Disamping pemenuhan dengan 
sejumlah variasi produk batik, industry juga melayani konsumen luar negeri yaitu Malaysia. Kondisi ini menurut Mc Calman, Paton (1992) yang menjelaskan tuntutan perubahan berasal dari perubahan eksternal yang sedang dihadapi oleh kebanyakan organisasi modern dewasa ini di dunia internasional diantaranya akan timbul sebuah pasar global yang lebih luas, yang menjadi lebih "kecil" karena meningkatnya unsur persaingan dari luar negeri.

Penyebab kedua yaitu faktor faktor keinginan untuk meningkatkan pendapatan para pengusaha batik. Faktor ini juga menjadi salah satu alasan untuk melakukan perubahan, seperti yang disampaikan oleh humas Batik Merak Manis berikut:

"Usaha batik kami dari segi pendapatan
sebenarnya sudah stabil, dengan artian
pendapatan yang kami terima tidak
kurang maupun kelebihan pendapatan,
namun dengan adanya perubahan yang
dilakukan diharapkan ada peningkatan
biarpun sedikit" (wawancara dengan
bapak Heri 27 Maret 2018).

Kondisi ini di dukung keinginan para karyawan terhadap gaji yang rendah, sementara kemampuan perusahaan tidak cukup untuk meningkatkan kesejahteraan karyawan, sehingga kondisi ini juga mendukung terjadinya perubahan. Kondisi ini sesuai penyebab perubahan menurut Siagian (1997) yang memasukan pertimbangan ekonomi, dimana tidak sedikit keluarga yang mengalami mengalami tekanan ekonomi dalam artin bahwa penghasilan nafkah utama, yang umumnya adalah para suami masih dirasakan belum mencukupi, sehingga para wanita akhirnya membantu meningkatan pendapatan tersebut dengan bekerja di luar rumah tangga.

Penyebab ketiga yaitu adanya persaingan dari kompetitor pengusaha batik, sebagaimana diungkapkan oleh pengusaha batik bahwa mayoritas pengusaha batik untuk menghindari persaingan harus menciptakan produk yang berbeda, teknologi produksi yang maju. Sebagaimana penjelasan Mc Calman, Paton (1992) bahwa perubahan organisasi di picu karena tempat kerja yang berubah, dan terjadinya kelangkaan ketrampilanketrrampilan menyebabkan timbunya kebutuhan akan karyawan-karyawan non tradisional.Demikian juga menurut pemilik batik yang lain bahwa ada kompetitor yang sangat kuatyang lokasinya dekat dengan Laweyan, sehingga menyebabkan para pengusaha batik dan pengurus forum di Laweyan harus bekerja keras (istilah jawa "pontang-panting")untuk mengimbanginya". Hasil pengamatan peneliti bahwa menemukan bahwa disamping pesaing bersal dari perusahaan batik besar, juga karena gempuran industry batik dari kota Pekalongan dan Cirebon yang terkenal lebih murah juga ikut mempengaruhi perubahan industri batik di Laweyan.

Penyebab keempatadalah karena kondisi perekonomian di Indonesia yang fluktuatif. Kondisi perekonomian di Indonesia yang fluktuatif, dimana dalam beberapa tahun terakhir mata uang rupiah mengalami pelemahan yang signifikan sedangkan sumber bahan baku kain seperti kapas, crayon dan sutera berasal dari Cina. Sebagaimana diungkapkan oleh pemilik Batik Puspa Kencana:

"Ketersediaan bahan baku di Laweyan
sendiri sangat melimpah, hanya saja
Indonesia belum mampu memenuhi
kebutuhan bahan dasar tekstil seperti
kapas, crayon dan sutera untuk produksi
dalam negeri. Sehingga bahan baku batik
(kain) harganya sangat tergantung nilai
tukar mata uang" (wawancara dengan
bapak Ahmad 22 Maret 2018).

Dalam bidang pertekstilan, Indonesia belum mampu memenuhi kebutuhan bahan dasar tekstil seperti kapas, crayon dan sutera untuk produksi dalam negeri. Sehingga bahan baku batik (kain) harus mengimpor dari negara lain yang harganya sangat tergantung nilai tukar mata uang.

Penyebab kelima adalah faktor pemerintah, khususnya Pemerintah Kota Surakarta, dimana pemerintah menjadi pendorong perubahan dengan adanya mengadakan pelatihan (trainning) untuk menciptakan kreasi dan inovasi produk batik. Hal ini menjadi salah satu faktor penyebab perubahan dari lingkungan eksternal, sebagaimana diungkapkan oleh pemilik Batik Halus Puspa Kencana berikut; 
"Pemerintah melalui DEKRANASDA atau dewan yang menangani desain batik daerah seperti Riau dengan Batik Melayu, Lampung dengan batik Lampung dan Batik Tidayu dari kerajaan Ketapang. Kreasi ini menambah semarak dunia permotifan batik, dimana motif batik menjadi beragam dan mendorong peningkatan pesanan batik dari pelanggan dalam negeri, karena pada umumnya mereka hanya bisa mengahasilkan desain atau motif tetapi tidak bisa mengeksekusinya menjadi batik. Sehingga dalam proses pelaksanaan eksekusi motif menjadi batik dilimpahkan ke pengrajin batik di kota Pekalongan ataupun Surakarta" (wawancara dengan bapak Ahmad 22 Maret 2018).

Temuanpenelitianinihampersamadengan temuan penelitian Djoemad Tjiptowardojo (2010) yang meneliti model teknik stratejik peningkatan mutu Perguruan Tinggi Swasta di Kota Bandung. Temuan penelitian ini berimplikasi pada pentingnya peningkatan peranan dan dukungan pemerintah dan juga pihak-pihak 'stakeholders' lembaga terhadap program peningkatan mutu pendidikan melalui upaya-upaya peningkatan mutu dosen, administrasi/manajemen lembaga dan saranaprasarana pembelajaran.

Penyebab perubahan yang keenam adalah masalah naiknya tingkat pendidikan dan pengembangan SDM terutama pimpinan perusahaan batik. Pendidikan menjadi faktor penyebabperubahan dari dalam organisasi, sebagaimana yang disampaikan oleh karyawan dari Batik Gress Tenan berikut;

"Yang punya pabrik ini kan masih bujang mas, terus sekolahnya juga tinggi dan modalnya ada. Maka enggak perlu heran mas kalo pabrik milik anaknya pak Jono ini lebih besar ketimbang punya bapaknya" (wawancara dengan bapak SY 8 April 2018).

Dari hasil wawancara kondisi tersebut sesuai dengan faktor-faktor rujukan Kasali (2005) dimana faktor penyebab perubahan yang efektif idealnya berubah sendiri, dimana syarat untuk berubah sendiri adalah adanya proses belajar dan selalu beradaptasi dengan zaman.Kondisi seperti ini hamper sama dengan hasil penelitian Maheshwari dan Vohra (2015) dengan delapan proposisi disajikan untuk membangun sebuah kerangka kerja konseptual terpadu mengidentifikasi praktik HR kritis selama perubahan organisasi dan dampaknya pada persepsi karyawan dan komitmen untuk berubah. Temuan studi ini menunjukkan bahwa praktik SDM yang dilakukan di wilayah perusahaan maka disebabkan budaya, kepemimpinan mengalami peningkatan. Demikian juga lintas fungsional integrasi, pelatihan, komunikasi dan teknologi jika diperkenalkan dan dilaksanakan secara positif akan mempengaruhi persepsi karyawan, mengurangi resistensi dan meningkatkan komitmen untuk berubah.

Hasil penelitian ini berbeda dengan hasil penelitian penelitian Anjali (2015) yang meneliti sebuah mekanisme pascaintegrasi perubahan dilakukan oleh lima merger multinasional dan akuisisi ( $\mathrm{M} \& \mathrm{~A}$ ) transaksi terjadi dalam konteks India. Hasil penelitian tersebut menunjukkan bahwa organisasi yang telah mengadakan perubahan maka mekanisme integrasi manusia diberi kepercayaan karena juga memendam karyawan sangat berkomitmen dari rekanrekan organisasi mereka, sedangkan transaksi di mana tujuan integrasi tugas diberikan preferensi sementara mengabaikan integrasi manusia, karyawan mengembangkan emosi negatif dari kemarahan dan rasa tidak aman karena mereka yang baru bergabung perusahaan.

Penyebab kedelapan dari hasil observasi tim peneliti dilapangan adalah faktor lingkungan sekitar, dimana banyak industri batik berusaha menyamai proses pembatikan yang dilakukan oleh industri batik yang sudah mapan yang pemaikan waktunya lebih efisien, selain itu kemudahan bertransaksi nontunai dengan nilai trasnsaksi yang besar. Penyesuaian tersebut antara lain proses pewarnaan kain yang mayoritas sudah menggunakan metode tolet atau menggunakan kuas yang terbuat dari kain dan dililitkan pada sebuah kayu kecil, sedangkan dalam mempermudah transaksi para industri batik sudah mulai menyediakan kartu kredit maupun kartu debit. Faktor ini jika merujuk istilah Tjitra dkk (2012) adalah perubahan yang bersifat adaptif atau menyesuaikan dengan kemajuan-kemajuan yang telah digunakan oleh industri lain.

Kondisi seperti ini sesuai hasil penelitian Sugito (2011) menunjukan bahwa perubahan di 
sebuah organisasi ternyata menjadi bagian dari pengembangan perusahaan karena pengaruh lingkungan. Jika manajemen menemukan perusahaan berhenti berkembang atau tidak dapat maju maka perusahaan harus berani melakukan kebijakan-kebijakan yang berani, meskipun dirasakan oleh seluruh steakholder ekstrim pada awalnya. Perubahan ternyata bukan keterpaksaan, tetapi sudah terbukti menjadi sebuah kebutuhan bagi perusahaan yang ingin maju dan tetap survivel.

\section{Dampak Perubahan}

Perubahan selalu mempunyai efek, karena sejatinya perubahan dilakukan dengan tujuan adanya peningkatan kemampuan perusahaan ataupun memperbaiki kekurangan-kekurangan yang ada pada periode sebelumnya. Adapun efek atau dampak dari perubahan yang pertama adalah bertambah luasnya pasar dari penjualan produk, sebagaimana diungkapkan oleh pemilik Batik Puspa Kencana berikut;

"Pangsa pasar dari batik saya adalah masyarakat Malaysia (70\%) dan sisanya adalah pasar dalam negeri, meski demikian dampak yang saya rasakan adalah penjualan didalam negeri mengalami peningkatan separuhnya. Selain itu dampak yang kami rasakan setelah mengikuti FPKBL mendapatkan kemudahan dalam mengajukan pinjaman ke bank" (wawancara dengan bapak Ahmad 22 Maret 2018).

Senada dengan Batik Puspa Kencana, Batik Merak Manis pun mengalami dampak yang sama terhadap penjualan dan pendapatan mereka setelah adanya perubahan. Sebagaimana penuturan dari narasumber batik merak manis berikut;

"Dampaknya terhadap penjualan maupun income memang ada, bukan bermaksud mendeskriditkan FPKBL, tapi kan Merak Manis sudah start dahulu, sehingga apa yang mereka berikan terutama dalam pelatihan. Peranan yang dipegang FPKBL selama ini adalah sebagai penyambung informasi dari pemkot Surakarta kepada pelaku industry batik di Laweyan, seperti menyampaikan even-even yang diselenggarakan oleh pemerintah, contohnya hari jadi kota Surakarta, Solo great sale, gong xi fa chai dan lainnya" (wawancara dengan bapak Heri 29 Maret 2018).

Dampak yang kedua adalah meningkatnya permintaan atau pesanan yang diterima oleh industri batik, hal ini dikarenakan industri batik yang dimiliki sudah mempunyai identitas berupa showroom, sehingga para pelanggan ataupun calon pelanggan mudah untuk mengingat atau mencarinya. Beberapa pengusaha pada awalnya belum mempunyai showroom, dimana proses penjualan langsung ke pengecer, sehingga harus mencari pengecer terlebih dahulu, tapi sekarang pembeli sudah mulai datang ke showroom untuk membeli secara langsung ataupun membuat pesanan. Bahkan beberapa tahun lalu sempat ada pesanan dari negara Laos meskipun tidak mengikat industry batik.

Dampak ketiga dari perubahan organisasi yang dilakukan Industri Batik Laweyan adalah keamanan dan kenyamanan karyawan dalam bekerja. Para karyawan yang bekerja di industri Batik Laweyan merasa lebih nyaman dalam bekerja, karena setelah terjadinya perubahan, maka pabrik menjadi bersih, luas dan penataan letaknya sangat baik. Dari pengamatantim peneliti, para pekerja lebih terjalin kerjasama timnya sehingga gesekangesekan atau kesalahan komunikasi itu sangat sedikit. Hal ini terjadi karena kondisi pabrik yang bersih dan tata letak pegawainya yang sesuai.

Dampak selanjutnya keempat yang dirasakan oleh karyawan adalah meningkatnya taraf kehidupan yang diakibatkan oleh kompensasi yang diterima, sebagaimana hasil wawancara dengan karyawan Batik Gress Tenan berikut;

"Kan pabrik ini yang punya sekarang anaknya pak Jono mas, dimana usianya masih muda dan di tunjang pendidikan yang memadai jadi tingkat gaji yang kami peroleh lumayan lah mas. Dibanding UMR masih tinggi upah kami, terus pemilik memberikan kepercayaan penuh kepada pegawai sehingga meskipun tidak dikontrol kami tetep bekerja masuk dari jam 8 sampai jam 4 sore. Apalagi kan disini setiap hari tingkat produksinya tidak mesti mas, tapi semenjak pabrik 
ini dibawahi oleh mas Arif pesanan yang datang itu jadi stabil mas. Masalahnya kami juga enggak enak mas, masak digaji gede kerjaannya tidak tetap" (wawancara dengan bapak SY 8 April 2018).

Dampak kelima adalah dari perubahan dalam proses pembatikan memberikan efek terjadinya efisiensi dan efektifitas waktu serta tenaga yang digunakan. Para pekerja batik merasakan setelah perubahan organisasi terutama dari segi teknik membatik, mereka bekerja menjadilebih mudah dan cepat. Hal ini dikuatkan hasil pengamatan timpeneliti di beberapa lokasi, dimana proses pewarnaan dengan cara penoletan memang lebih cepat, untuk mewarnai sebuah kain waktu yang diperlukan hanya sekitar satu jam.Hal ini, senada dengan yang disampaikan oleh SP, karyawan Batik Gress Tenan pun merasakan dampak yang serupa. Sebagaimana wawancara berikut:

"Kan kalo proses pelepasan malam kayak gini pakainya air panas mas, terus ini juga kan volume airnya banyak. Dulu waktu masih pakai kayu bakar lama banget mas, tapi setelah pakai kompor gas ini istilahnya bisa disengkakne lah mas" (wawancara dengan bapak SG 8 April 2018).

Pernyataan kedua karyawan diatas diperkuat dengan pernyataan karyawan batik Supriyarso berikut;

"Dulu memanaskan malamnya masih pake arang mas, jadi pekerjaan dalam membatik itu dobel, karena harus ngipasi arang. Setelah pake kompor gas pekerjaannya jadi lebih ringan, selain itu asapnya tidak ada mas" (wawancara dengan bapak JK 9 April 2018).

\section{Proses Perubahan}

Dari hasil pengamatan dan wawancara, makaperubahan diawali perubahan teknik produksi, yang semula menggunakan batik cap tadisional menjadi batik printing semi modern, sebagaimana hasil wawancara dengan mas Arif 28 maret 2017 (lihat proses perubahan). Perubahan teknik yang lain terjadi dari pencelupan yang semula pemanas menggunakan tungku tadisional atau kompor minyak, maka mengalami perubahan menggunakan pemanas dari kompor gas bahkan ada yang menggunakan mesin pemanas. Demikian juga proses penjemuran kain batik yang semula di jemur di luar pabrik dengan mengandalkan sinar matahari, di beberapa perusahaan sudah menggunakan suhu ruangan yang teratur.

Perubahan lain hasil pengamatan peneliti adalah pada proses produksi, dimana sudah digantikannya peran kayu bakar oleh kompor gas dalam pemanasan malam serta dalam proses pemanasan air ketika pelunturan malam. Dalam urutan pelaksaan membatik pun sekarang lebih fleksibel, jika dahulu pewarnaan kain dilakukan setelah pemberian motif, namun sekarang sudah ada batik yang proses pewarnaannya lebih dahulu daripada proses pemotifan.

Tahapanperubahan keduaadalah setelah produk jadi, antar pengusaha batik saling berinteraksi dan berkomunikasi secara intensif dan saling menitipkan produk antar pengusaha batik, sebagaimana wawancara dengan batik Puspa kencana berikut;

"Kami para pengusaha batik saling melakukan interaksi penjualan atau penitipan barang di show room, dengan cara memberikan potongan harga. Sehingga harga yang dijual tetap sama dengan di show room asal" (wawancara dengan bapak Ahmad 22 Maret 2018).

Untuk mempererat rasa kekeluargaan sekaligus mengakomodir antar pengusaha batik, setiap bulan diadakan pertemuan pada tanggal 25 atau sering disebut dengan "selawenan". Sebagaimana wawancara dengan humas Batik Merak Manis berikut;

"Setiap tanggal 25 ada pertemuan antar pengusaha batik, kebetulan pemilik Merak Manis dianggap masyarakat sebagai salah satu sesepuh, sehingga sering dimintai pendapat ataupun masukan-masukan oleh pengurus forum" (wawancara dengan bapak Heri 28 Maret 2018).

Langkah perubahan yang ketiga yang dilakukan pengusaha batik adalah pengintensifan bauran promosi (promotional mix).Strategi tersebut diantaranya pembuatan 
web, mengikuti pameran-pameran yang diadakan oleh pemerintah seperti Solo Great Sale, Inacraft, gong xi fa chai, HUT kota Solo dan lain-lain. Promosi tradisional juga dilakukan yang selama ini dinilai cukup efektif adalah melalui "gethok tular" (pembicaraan dari mulut ke mulut). Langkah promosi ini bila dikaitkan dengan teori yang dikemukakan oleh Lupiyoadi (2013) tentang word of the mouth (WoM) atau informasi dari mulut ke mulut dampaknya sangat besar terhadap pemasaran dibandingkan dengan aktivitas komunikasi lainnya.Senada dengan penuturan Batik Merak Manis, langkah serupa juga dilakukan oleh pemilik Batik Halus Puspa Kencana.

"Saya juga mengisi seminar masalah ekspor-impor terutama tentang batik di perguruan tinggi, disitulah kadangkadang setelah selesai acara ada yang tertarik dengan produk kami" (wawancara dengan bapak Ahmad 22 Maret 2018).

Tahapan perubahanyang keempat yang dilakuan oleh para pengusaha batik adalah mengadakan kemitran usaha dengan perguruan tinggi, instansi dan kantor-kantor baik swasta maupun pemerintah. Pengusaha batik menerima pesanan seragam batik yang dilakukan oleh instansi pemerintah mupun perguruan tinggi yang motifnya telah mereka siapkan. Sebagaimana yang disampaikan oleh pemilik batik Puspa Kencana berikut;

"Sering mas dapat pesanan batik dari Pemkab ataupun perguruan tinggi. Dulu ada dari Pemkab dan beberapa sekolah di Kalimantan, ini yang terakhir ada pesanan dari Universitas Lampung. Rata-rata mereka sudah menyiapkan motifnya, lalu mereka memilih bahan yang akan digunakan. Selain itu sekarang ini hampir seluruh daerah mampu membuat motif sendiri, karena ada lembaga yang menangani itu mas yaitu DEKRANASDA, tapi meraka tidak bias untuk mengeksekusinya menjadi batik. Sehingga untuk bagian eksekusi menjadi batik larinya kalo tidak ke Pekalongan ya Solo" (wawancara dengan bapak Ahmad 22 Maret 2018).
Tahapan perubahan yang kelima yaitu para pengusaha batik memanfaatkan teknologi transaksi perbankan yang modern. Dari hasil pengamatan (observasi), peneliti menemukan bahwa hampir seluruh show room batik di Laweyan telah melayani transaksi pembayaran tidak langsung atau menggunakan kartu debit maupun kredit. Hal ini dilakukan untuk mempermudah konsumen yang melakukan pembelian dalam membayar, terutama yang melakukan transaksi dalam jumlah besar karena lebih terjamin keamanannya. Langkahlangkah yang dilakukan diatas jika merujuk istilah Clarke (1999), merupakan perubahan yang dilandasi oleh faktor eksternal atau yang dihubungkan dengan perubahan yang terjadi di pasar.

Tahapan perubahan keenam adalah menciptakan produk yang berbeda dengan industrilain serta didukung tekonologi produksi untuk menciptakan kulitas dan keberagamaan produk, sebagaimana disampaikan oleh humas dari Batik Merak Manis berikut;

"Jika pada umumnya batik itu identik dengan pakaian maka anda akan menjumpai hal yang berbeda di Merak Manis, karena mayoritas produk kami adalah yang berhubungan dengan perlengkapan rumah tangga seperti taplak meja dan sprei, sisanya baru mengarah ke pakaian. Sehingga kami mempunyai ciri khas tersendiri di Kampung Laweyan ini" (wawancara dengan bapak Heri 29 Maret 2018).

Tahapan ini sesuai hasil penelitian Djoemad Tjiptowardojo (2010) yang meneliti model teknik stratejik peningkatan mutu Perguruan Tinggi Swasta di Kota Bandung berkesimpulan bahwa untuk peningkatan mutu penyelenggaraan pendidikan tinggi dalam kerangka otonomi pendidikan tinggi dan globalisasi, dapat dilakukan dengan menerapkan manajemen stratejik melalui penerapan strategi-strategi peningkatan mutu dosen dan staf, mutu layanan administrasi/ manajemen, dan peningkatan mutu sarana dan prasarana kelembagaan.

Kalau di kaji secara menyeluruh tahapantahapan perubahan dalam Industri Batik Laweyan hampir sama dengan tahapan model Greiner (1972), dimana tipologi perubahan 
yang ada dalam perusahaan berkaitan dengan tahapan yang ada dalam perusahaan. Tahapan tersebut antara lain : (1) tahap Entrepeneurial, dimana dalam tahap ini,tantangannya adalah bagaimaa menyediakan produk atau jasa, sementara upaya bertahan hidup (survival) jadi strategi terpenting. (2) Tahap Kolektif, pada tahap ini, perusahaan semakin berbentuk. Bagian-bagian fungsi dirumuskan dan pembagaian kerja jadi tema dominant. (3) Tahap Formalisasi, pada tahap ini sistem komunikasi dan kontrol makin formal, tugas manajemen puncak untk membuat keputusan strategis dan mengimplimentasikan kebijakan dipisahkan dari tugas manajemen tengah yang bertugas menjalankan dan mengatasi keputusan operasional. (4) Tingkat elaborasi, dimana tahap ini perushaan mencapai tingkat perubahan strategis karena telah melewati puncak (plateau) pada kurva pertumbuhannya dan kinerja mulai menurun.

Sedangkan tahapan perubahan jika dikaitkan model perilaku industryStrebel (1996), maka arah tahapanya berbeda dimana model Strebel (1996) mengkaitkan pada lingkungan kompetitif perusahaan. Teori tipologi perubahan ini bisa juga disebut "daur perilaku kompetitif evolusioner" dimana memperkenalkan ide "breakpoint", yaitu periode dimana perusahaan harus merubah strategi mereka untuk merespon perubahan perilaku kompetitor atau pesaing.

Tahapan perubahan kalau kita kaji dari teori "Proses Perubahan", maka dalam melakukan setiap perubahan di setiap industri tak semuanya sama, ada beberapa perusahaan yang melakukan perubahan secara strategis dan cepat tapi ada yang lambat dan juga ada yang tenang. Menurut Grundy Theory (dalam Sulaksana, 1994), dimana teori ini menjelaskan ada tiga jenis perubahan yaitu : (1) Smooth Incremental Change, dimana perubahan ini terjadi sifatnya lambat, sistematis dan dapat diprediksikan, rentetan perubahan berlangsung pada kecepatan konstan. (2) Bumphy Incremental Change, sifat perubahan ini mempunyai karakter tenang, teratur dan terjadi secara periodik. Pemicu perubahan jenis ini selain mencakup perubahan lingkungan organisasi juga bersumber dari perubahan internal seperti tuntutan efisiensi, dan perubahan perbaikan metode kerja. (3) Discountinous Change, Perubahan ini ditandai oleh pergeseran-pergeseran cepat atas strategi, struktur atau budaya, baik secara masingmasing atau ketiganya sekaligus.

Proses perubahan yang terjadi di Industri Batik Laweyan kalau kita kaitkan teori Grundy tersebut, maka karaktenya lebih mengarah pada Bumphy Incremental Change, dimana perubahan organisasi berjalan secara tenang, dan teratur. Perubahan diawali perubahan teknik produksi hingga penataan produk jadi. Sebagaimana penuturan dari pemilik Batik Gress Tenan;

"Sebenarnya tidak banyak sih mas perubahan-perubahan yang dilakukan, mungkin cuma pengadaan showroom, mulai memroduksi batik printing serta penataan letak saja" (wawancara dengan mas Arif 28 maret 2018).

Penuturan yang sama juga disampaikan oleh pemilik Batik Puspa Kencana, yang juga merubah arah fokus bisnis dan cara kerja;

"Pada tahun 1994saya bekerjasama dengan salah satu perusahaan tekstil dari Malaysia, awalnya hanya sebagai penyuplai bahan baku namun setelah PT ARR kewalahan memenuhi permintaan, mereka memberikan bantuan 4 tenaga ahli untuk mengajari motif, teknik pewarnaan dan mode fashion dari Malaysia serta peralatannya. Teknik pewarnaan yang diajarkan tenaga ahli tersebut kini hampir digunakan oleh keseluruhan industri batik yang ada disini" (wawancara dengan bapak Ahmad 22 Maret 2018).

Senada dengan Batik Gress Tenan dan Batik Halus Puspa Kencana, Batik Merak Manis pun melakukan perubahan yang bersifat pengembangan Manajemen Pemasaran, sebagaimana diungkapkan oleh bagian humas dari Batik Merak Manis berikut ini;

"Usaha batik ini berusaha menerapkan perkembangan teknonologi yang ada, menambah gerai di luarkota, menyediakan ruangan untuk tamu yang berkunjung seperti kunjungan dari pemerintah daerah ataupun kota yang ingin melihat-lihat maupun melakukan transaksi pembelian. Karena dengan hal demikian secara 
tidak langsung telah melakukan promosi secara gethok tular yang terbukti sangat efektif dan tidak memakan biaya, selain itu kami melakukan pengkaderan kepada pekerja supaya setiap bagian ada yang membawahi" (wawancara dengan bapak Heri 29 Maret 2018).

Langkah perubahan yang dilakukan oleh Batik Mahkota memang sedikit berbeda, karakter perubahan berlangsung lebih cepat, strategis dan reaktif. Sifat perubahan ini kalau berdasarkan teori Grundy seperti "Discountinous Change. Hal ini dikarenakan pemiliknya adalah ketua forum pengembang kawasan. Sehingga langkah yang dilakukan lebih cepat strategis dan selain digunakan untuk industrinya juga diajarkan kepada industri batik lainnya, sebagaimana wawancara dengan pemilik Batik Mahkota berikut:

\footnotetext{
"Kami mulai mematenkan batik Heritage yang dibantu fakultas hukum salah satu perguruan tinggi negeri di Yogyakarta serta membangun tugu batik yang berlokasi di pinggir jalan utama kota Surakarta, selain itu kami juga mencoba pewarnaan berbahan alami dan ramah lingkungan yang di dukung oleh salah satu perguruan tinggi swasta di kota Surakarta ini. Karena selama ini pewarna alami itu identik dengan waktu yang lama, namun berkat riset tersebut proses pewarnaan hanya membutuhkan waktu beberapa jam saja" (wawancara dengan bapak Alpha 15 April 2018).
}

Kondisi perubahan ini hamper sama dengan temuan penelitian Rindaningsih (2012) tentang pengembangan model manajemen Stratejik di sebuah lembaga pendidikan di Sidoarjo Jawa Timur yang menghasilkan temuan bahwa pengembangan stratejik sangat efektif dalam mengatasi berbagai problematik di sekolahan dan perlunya peran maksimal pimpinan/kepala sekolah dalam proses perubahan. Demikian juga hasil penelitian Abdul Mukhlis (2010) tentang implementasi manajemen strategis dalam upaya peningkatan mutu pendidikan pada pondok pesantren di Jombang Jawa Timur menghasilkan temuan bahwa implementasi manajemen strategis dalam upaya peningkatan mutu pendidikan sudah terlaksana dengan baik di lembaga pesantren tersebut. Usaha peningkatan mutu pendidikan mulai meningkat dan terarah karena penerapan manajemen strategis yang diterapkan oleh Pesantren dapat dilaksanakan dan tercapai dengan baik.

Apabila dikaitkan dengan teori kelompok French dan Bell (1990), maka proses perubahan sudah menuju arah yang benar, dimana untuk mendorong perubahan, maka strateginya tidak hanya berkonsentrasi pada pengubahan perilaku individu. Individu secara sendirisendiri mendapat tekanan dari kelompok yang menyebabkan harus beradaptasi. Maka fokus perubahan mesti di pusatkan pada tataran kelompok dan selayaknya berkonsentrasi untuk mempengaruhi dan mengubah norma, peran, dan nilai kelompok. Demikian juga arah perubahan di industri Batik Laweyan maka sesuai jika dikaitkan dengan Mazhab Dinamika Kelompok Model Lewin (dalam Sulaksana, 2004), dimana menekankan pada pencapaian perubahan organisasi melalui tim atau kelompok kerja, daripada individu. Bahwa orang-orang dalam organisasi bekerja dalam kelompok, maka perilaku individual bisa dimodifikasi atau diubah dalam kaitannya dengan praktek-praktek dan norma kelompok.

\section{Faktor Pendukung Perubahan}

Perubahan organisasi akan mudah dilakukan jika terdapat faktor pendukung, semakin banyak faktor pendukung yang ada maka tujuan perubahan yang dicanangkan akan dapat direalisasikan. Faktor pendukung perubahan yang pertama adalah dukungan dari pemerintah. Sebagaimana wawancara dengan pemilik Batik Puspa Kencana berikut;

"Dari pemerintah kita mendapatkan pembinaan mas, diantaranya dari departemen koperasi memberikan pinjaman lunak, dari departemen perindustrian memberikan pelatihanpelatihan dan dari departemen pariwisata membantu pembentukan cluster batik" (wawancara dengan bapak Ahmad 22 Maret 2018).

Senada dengan Batik Puspa Kencana, Batik Merak Manis pun mengutarakan hal yang sama, sebagaimana wawancara dengan humas dari Batik Merak Manis Berikut: 
"Solo itu identik dengan batik, batik itu identik dengan Laweyan, ayo wong Laweyan kalian ini sebagai sentra kerajinan batik ayo bangkitkan kembali kejayaan industri batik di Laweyan, nanti tak bantu share ke publik" (wawancara dengan bapak Heri 28 Maret 2018).

Faktor pendukung yang kedua adalah adanya lembaga pelindung. Lembaga ini bernama FPKBL (Forum Pengembangan Komunitas Batik Laweyan). Lembaga ini berperan sebagai pelindung sekaligus pusat pengelolaan perubahan di industry Batik Laweyan. Sebagaimana yang diungkapkan pemilik Batik Gress Tenan berikut;

\begin{abstract}
"Semenjak hadirnya FPKBL itu banyak banget mas manfaat yang kami terima, karena ada organisasi resmi yang menangani. Forum memberikan pelatihan-pelatihan baik dalam hal proses maupun pengembangan usaha serta mendatangkan tamu baik untuk berbelanja maupun belajar membatik. Dulu kami hanya memproduksi batik lalu dijual dan belum mengenal showroom ataupun strategi dalam produksi maupun penjualan" (wawancara dengan Arif 28 Maret 2018).
\end{abstract}

Temuan penelitian ini hampir serupa dari hasil penelitian Anna Pluta \&Aleksandra Rudawska (2016) yang meneliti model pendekatan holistik terhadap lembaga Sumberdaya Manusia (Human Resource Management) dalam mendukung situasi percepatan organisasi. Peneliti merumuskan bahwa pendekatan holistik untuk Human ResourceManagement sebagai lembaga yang membantu dalam menjaga sumber daya yang berkelanjutan individu karyawan dalam situasi perubahan organisasi terus menerus dan tekanan waktu yang lebih lanjut dapat mencegah dari kelelahan sumber daya individu. Hasil penelitian lainnya dalam situasi fungsi percepatan HRM organisasi memainkan peran penting dalam mempertahankan sumber daya individu karyawan untuk meminimalkan ancaman stres kerja dan burnout lebih lanjut. praktik HR harus menerapkan multidimensi sumber daya individu dan ancaman itu secara holistik bertujuan mempertahankan keempat potensi - spiritual, intelektual, emosional dan fisik. Perbedaannya FPKBL adalah lembaga diluar organisasi perusahaan, sedangkan HRM adalah lembaga internal perusahaan yang berubah.

Faktor pendukung perubahan yang ketigayaitu meningkatnya tingkat pendidikan pengelola industry batik, sebagaimana wawancara dengan pemilik batik Puspa Kencana berikut;

"Kalo jaman dahulu anak-anak dari juragan batik yang sudah sekolah sampai perguruan tinggi lebih memilih bekerja di perusahaan besar mas, tapi sekarang udah kebalikannya, mereka bisa bekerja di industri batik sendiri (kebanyakan milik bapaknya) sudah mengenal manajemen atau pengelolaan yang baik" (wawancara dengan bapak Ahmad 29 Maret 2018).

Senada dengan bapak Ahmad, pemilik Batik Mahkota Laweyan pun mengutarakan hal yang serupa, sebagaimana wawancara dengan ketua FPKBL berikut:

"Kita itu enggak bisa melihat potensi yang ada di lingkungan kita sendiri. Hal ini dikarenakan tingkat pendidikan pada saat itu masih rendah, sehingga pola pikir yang ada pada saat itu kalo tidak jualan batik ya pemrosesan batik. Namun, setelah banyak dari anak pengusaha batik yang disekolahkan ke perguruan tinggi, maka mereka mulai mau menerima masukan-masukan yang berasal dari luar, dan itu memberikan kemajuan yang sangat berarti buat industri batik yang ada" (wawancara dengan bapak Alpha 15 April 2018).

Faktor pendukung ini hampir sama dengan hasil penelitian Rodriguez et.all (2016) yang menganalisis perubahan organisasi tertentu yang terjadi setelah privatisasi, dimana hasil penelitiannya menjelaskan bahwa variabel pendukung perubahan adalah kebebasan dalam berkreasi terutama dalam taktikperubahan yang lebih besar setelah privatisasi. Demikian juga kepentingan kepemilikan baru perusahaan berdampak pada strategi perusahaan setelah privatisasi. Maknanya kebebasan dalam berkreasi seringkali karena meningkatnya 
factor pendidikan, pengembangan bakat dan kreasi.

Faktor pendukung yang keempat adalah para pengusaha mulai mengenal teknologi baik teknologi produksi dan informasi. Teknologi produksi adalah melakukan inovasi terhadap bahan-bahan yang digunakan dalam proses pewarnaan dan bahan-bahan tersebut mudah didapati, sebagaimana penuturan pemilik Batik Mahkota Laweyan:

"Sekarang kami mulai menggunakan tanaman indigo sebagai bahan dasar pewarnaan batik terutama yang bewarna biru. Tanaman ini mudah dijumpai disekitaran rel kereta api, dan kami berusaha membudidayakannya di belakang rumah bapak ahmad sulaiman" (wawancara dengan bapak Alpha 5 April 2018).

Faktor ini sesuai hasil penelitain Wedsastro Gogo H (2012) yang menguji secara empiris pengaruh faktor pemacu dalam perubahan akuntansi manajemen, yaitu bahwa faktor yang mempercepat perubahan akuntansi manajemen adalah dukungan penerapan Teknologi informasi (TI), ekspektasi, dewan direksi. Selain itu faktor sikap kontrol perilaku dan lingkungan juga mendukung perubahan akuntansi manajemen. Sedangkan faktor yang tidak berkaitan dengan perubahan organisasi dari segi akuntansi manajemen adalah staf, biaya, profitabilitas, kualitas data, insentif, dan masalah keagenan.

\section{KESIMPULAN DAN SARAN}

\section{Kesimpulan}

Karakteristik perubahan organisasi di Industri Batik Laweyan:

1. Penyebab Perubahan organisasi:

karena pemenuhan kebutuhan dan selera konsumen, (2) adanya persaingan dari competitor pengusaha batik, (3) karena kondisi perekonomian di Indonesia yang fluktuatif. (4) Adanya masalah pendidikan dan kemampuan keuangan perusahaan batik, (5) faktor lingkungan sekitar.

2. Dampak perubahan, antara lain: (1) bertambahnya pasar dari penjualan produk, (2) meningkatnya permintaan atau pesanan yang diterima oleh industri batik, (3) meningkatnya taraf kehidupan yang diakibatkan oleh kompensasi yang diterima, (4) terjadinya efisiensi dan efektifitas waktu serta tenaga yang digunakan, (5) keuletan dan kegigihan pengurus dalam mengelola serta mengembangkan kawasan.

3. Proses pelaksanaan perubahan yang merupakan tahapan dalam melakukan setiap perubahan di industri batik Laweyan secara individu tidak semuanya sama, ada beberapa perusahaan yang melakukan perubahan secara radikal dan strategis seperti perubahan arah dan fokus bisnis, perubahan nilai-nilai dasar perusahaan dan perubahan cara kerja, ada beberapa perusahaan yang melakukan secara evolusi atau tahapan-tahapan.

4. Faktor pendukung perubahan, antara lain: (1) pihak pemerintah, (2) lembaga pelindung (Forum Persatuan Komunitas Pengusaha Batik Laweyan/ FPKBL), (3) Kebijakan perusahaan, (4) bahanbahan yang digunakan untuk melakukan inovasi dalam proses pewarnaan mudah didapatkan.

\section{Saran}

Dari analisis penyebab, akibat, faktor pendukung, faktor penghambat dan sumber penolakan terhadap perubahan, maka peneliti menyarankan baik kepada pengelola Industri Batik Laweyan, Pemkot Surakarta dan peneliti lain:

1. Bagi pengusaha batik di Industri Batik Laweyan dalam mengelola perubahan, maka memfokuskan pada upaya dikelompok pengusaha batik yang tergabung dalam FPKBL baik penanganan perubahan secara perusahaan individu maupun organisasional atau kelompok.

2. Bagi Pemerintah Kota Surakarta siap diajak bermitra bahkan mendukung sepenuhnya program kemitraan seperti mengadakan pendidikan dan pelatihan kerja, dalam hal ini Balai Latihan Kerja, Lembaga pelatihan atau Dewan Kesenian dan Kerajinan Nasional Daerah(DEKRANASDA). Pemkot Surakarta juga menyerukan pada Lembaga Keuangan baik konvensional 
maupun Lembaga Keuangan Syariah untuk mendukung perubahan tersebut dari sisi penambahan modal usaha.

3. Bagi peneliti lain, obyek penelitian bisa diperluas dengan menggunakan industri batik lainnya di seluruh Surakarta. Hal ini dikarenakan karakteristik perubahan organisasi lebih bervariatif dan lebih kompleks dan akan menghasilkan temuan penelitian yang lebih fenomena dan berguna untuk meningkatkan kinerja perusahaan.

\section{DAFTAR PUSTAKA}

Arikunto, Suharsiwi, 1996, Prosedur Penelitian: Suatu Pendekatan Praktek, Binarupa Aksara, Jakarta

Arsyad, Abdurrachman, 2013, Pengaruh Perubahan Organisasi terhadap Kinerja Karyawan (Studi Kasus Pertamina Terminal Bahan Bakar Minyak Bandung, Institut Manajemen Telkom Bandung

Bass, B.M. 1985, Leadership and performance beyond Expections. NewYork : Free Press

Berger, Lance, 2003, The Change Mangement handbook : A Road Map to Corporate Transformation, Mc.Graw Hill, USA

Effendy, Rusman and Ridwan , Nurazi and Paraningrum, 2009,Analisis Dampak Perubahan Organisasi Bagi Kinerja Pegawai di Lingkungan Skretariat Daerah Kota Bengkulu, Thesis, Fakultas Ekonomi UNPAD Bandung

Gibson. L \& Ivancevich,2001, Organizations(Behavior, structure and Process), Richard D. Irwin, Inc. terjemah PT. Binarupa aksara, Jakarta

Handoko T. Hani, 1996, Managemen Personalia, dan Sumber Daya Manusia, BPFE Yogyakarta.

Hasibuan, SP Malayu, 1997, Manajemen Sumberdaya Manusia. Penerbit PT Gunung Agung, Jakarta.

Heidjrachman Ranupandojo, 1993, ”Manajemen Personalia“, BPFE UGM,Yogyakarta.

Hellriegel, Don, John W. Slocum, Jr.,1996,Management, SouthWesternCollege Publishing. Ohio, U S A.

Henry Simmamora, 1995,”Manajemen Sumber Daya Manusia “,STIE YKPN,Yogyakarta

Jones, 2000, Organization Design, Process Reengenering, and Change Management, New york: Mc. Graw Hill Book Company, USA

Kaeter, M. (Inggris)"The Age of the Specialized Generalist," Training, desember 1993, hal. 48-53

Kast, Freeman and Rosenzweig, 1985, Organizations and Management, A System and Contingency Approach, Mc Graw Hill Book company, New York, USA

Kompas 21 September 2011, Ekspor Batik Indonesia meningkat, PT. Gramedia, Jakarta

Kreitner R \& Kinicki A, 2001, Organizational Behavior, Mc Graw Hill Companies, Inc. New York

Moleong, L.J., 2005, Metodologi Penelitian Kualitatif, Bandung PT. Remaja Rosdakarya

Kreitner, Robert\& Kinicki, Angelo, 2005, Organizational Behavior, Mc Graw Hill Companies, Inc. New York 
Latta,Gail F. (2015) "Modeling the cultural dynamics of resistance and facilitation: Interaction effects in the OC3 model of organizational change", Journal of Organizational Change Management, Vol. 28 Iss: 6, pp.1013 - 1037

Lukman Hakim \& Vivian Maharani, 2010, Analisis Perumusan Strategi Perusahaan Pada PT. Jamu Air Mancur Wonogiri, Penelitian Kolaborasi Dosen Mahasiswa, Prodi Manajemen UMS.

Maheshwari,Shweta; Veena Vohra (2015) "Identifying critical HR practices impacting employee perception and commitment during organizational change”, Journal of Organizational Change Management, Vol. 28 Iss: 5, pp.872 - 894

Michael Hammer dan James Champy, 2004, Reengineering the Corporation : A Manifesto for Business Revolution, SouthWesternCollege Publishing. Ohio, U S A.

Miftah, Thoha. 2008. Perilaku Organisasi; konsep dasar dan aplikasinya. Jakarta: PT Raja Grafindo Persada.

Muallimah, Atsarotul (2011) Implementasi Manajemen Perubahan Dalam Mewujudkan Rintisan Sekolah Bertaraf Internasional (RSBI) di SMPN Sidoarjo Undergraduate thesis, UIN Sunan Ampel Surabaya.

Nina Karlina, 2016, Pengaruh Perubahan Organisasi Terhadap Kinerja Perusahaan PDAM Kota Bandung, Jurnal Sosiohumaniora UNPAD Bandung

Nur Rahmanto, Choirudin (2010) Pengaruh antara variabel komitmen organisasi, perubahan organisasi, dan budaya organisasi terhadapefektivitas kerja, Program Pasca Sarjana Universitas Muhammadiyah Surakarta, Surakarta

Reksohadiprojo, Sukanto, \&Hani Handoko, 1997,Organisasi Perusahaan. BPFE Yogyakarta

Robbins, Stephen P., 2005, Organizational Behavior, Concept Contropversies and Applications, Prentice Hall Inc. USA. Terjemahan. Jakarta: P.T. Indeks Kelompok Gramedia.

Robbins, Stephen P.; Judge, Timothy A. (2008). Perilaku Organisasi Buku 2, Jakarta: Salemba Empat, Jakarta

Rodriguez,Gloria Cuevas; Villegas,Jaime Guerrero;\&Cabrera, Ramón Valle , (2016),"Corporate governance changes, firm strategy and compensation mechanisms in a privatization context”, Journal of Organizational Change Management, Vol. 29 Iss: 2, pp.199 - 221

Singarimbun, Masri dan Effendi, Sofyan.1995, Metode Penelitian Survey, Cetakan Kedua, PT Pustaka LP3S, Jakarta

Schein, Edgar, 2005, Organization Culture and Leadership, Jossey Bass, San Fransisco, USA

Sukanto R \& T. Hani Handoko, 1990, Organisasi Perusahaan, Penerbit BPFE, Yogyakarta

Winardi, 2009, Manajemen Perilaku Organisasi, Kencana, Prenada Media Group, Jakarta

Winardi, 2009, Teori Organisasi dan Pengorganisasian, PT. Raja Grafindo Rajawali Press, Jakarta

Wexley, K.N., Yukl, G.A., 1977, Organizational Behavior and Personal Psychology, Richard D. Irwin Inc., Homewood, Illinois.

Yin, K.R.,2006, Studi Kasus: Desain dan Metode, PT Raja Grafindo Persada Jakarta 